\title{
PLK4 wt Allele
}

National Cancer Institute

\section{Source}

National Cancer Institute. PLK4 wt Allele. NCI Thesaurus. Code C119602.

Human PLK4 wild-type allele is located in the vicinity of $4 \mathrm{q} 28$ and is approximately $18 \mathrm{~kb}$ in length. This allele, which encodes serine/threonine-protein kinase PLK4 protein, is involved in centriole duplication. 